\title{
COMPARATIVE STUDY IN LEPTOSPIROSIS AND ACUTE VIRAL HEPATITIS
}

\author{
Galya Gancheva, Chrisima Tzvetanova, Penka Ilieva, Iskra Simova \\ Department of Infectious Diseases, Epidemiology, Parasitology and Tropical \\ Medicine \\ Medical University, Pleven, Bulgaria
}

\section{SUMMARY:}

Retrospectively have been studied clinical signs and routine laboratory investigations of patients with leptospirosis $\left(\mathrm{n}_{1}=94\right)$ and acute viral hepatitis $(\mathrm{AVH})$ $\left(\mathrm{n}_{2}=1705\right)$. The comparison of results in two groups have revealed significant differences in the frequency of acute onset in leptospirosis and AVH with fever (respectively in $100 \%$ and $58,01 \% ; \mathrm{p}<0,005$ ); pains in calf muscles (in leptospirosis in $85,11 \%$, in AVH have not been observed); headache (resp. in 68,08 and $18,96 \%$; $p<0,005$ ); anorexia (resp. in 64,89 and $87,36 \% ; p<0,005$ ); lumbar pains (in leptospirosis in $40,43 \%$, in AVH have not been observed); clay colored stool (resp. in 6,38 and 93,60\%; $<<0,005$ ); heaviness in abdomen (resp. in 3,19 and 84,38\%; $<<0,005$ ); hepatic tenderness (resp. in 41,49 and $76,63 \% ; p<0,005$ ); conjunctival injection only in leptospirosis $(86,17 \%)$. Routine laboratory investigations have been demonstrated anemia, leucocytosis, granulocytosis, increased erythrocytes sedimentation rate (ESR) and thrombocytopenia significantly often in leptospirosis than in AVH $(p<0,005)$. The comparison of results of liver biochemical investigations have been established increased serum bilirubin in leptospirosis and $\mathrm{AVH}$ (resp. in 75,00 and 93,60\%; $<<0,05$ ); mildly increased aminotransferases activities in leptospirosis and extremely increased in AVH $(p<0,005)$; increased creatinkynase in leptospirosis; increased fibrinogen level in leptospirosis (av. $6,74 \mathrm{~g} / \mathrm{L}$ ), normal to decreased in AVH (av. 3,01 g/L) $(\mathrm{p}<0,005)$. Nitrogen parameters have been increased in leptospirosis with ARF.

Key words: leptospirosis, acute viral hepatitis, acute renal failure, liver biochemical parameters, creatinkynase, nitrogen parameters.

Leptospirosis at present is grossly underreported and a diagnostic dilemma because of its protean clinical manifestations. The spectrum of disease ranges from a mild inconsequential febrile illness to a severe fatal form presenting with multi organ failure conventionally called "Weil's disease $(1,3,6,14)$. The variability in the course of leptospirosis causes diagnostic problems with broad spectrum of diseases such as acute viral hepatitis (AVH), hemorrhagic fevers, dengue fever, typhoid fever, malaria, sepsis, etc $(1,3,4,6,14,15)$. In our practice most often is needed to distinguish leptospirosis and AVH (2). AVH and leptospirosis have certain similarity in clinical symptoms and syndromes. Disorders in liver functions have been observed in both diseases; diagnostic problems are not rare $(14,15)$.

The aim of this research is a comparison of leptospirosis and AVH purposed to establishment of significant differences which could play role as diagnostic criteria in clinical practice.

\section{MATERIALS AND METHODS:}

Retrospectively have been studied clinical signs and routine laboratory investigations of patients with leptospirosis $\left(\mathrm{n}_{1}=94\right)$ and AVH $\left(\mathrm{n}_{2}=1705\right)$ treated in Clinic of Infectious Diseases at University Hospital - Pleven, Bulgaria.

\section{RESULTS:}

Acute onset has been presented in leptospirosis and AVH respectively in $100 \%$ and $58,01 \%$. In leptospirosis often have been presented adynamia $(90,43 \%)$, pains in calf muscles $(85,11 \%)$, chills $(78,72 \%)$, headache $(68,08 \%)$, anorexia $(64,89 \%)$, generalized muscle pains $(52,13 \%)$. Anorexia $(87,36 \%)$, adynamia $(82,16 \%)$, myalgia $(31,55 \%)$, chills $(19,94 \%)$, headache $(18,96 \%)$ have been observed in AVH. Nausea and vomiting have been presented equally in leptospirosis and AVH, respectively $88,30 \%$ and $89,03 \%$ ( $>00,05)$. Hepatomegaly $(91,49 \%)$ and splenomegaly $(72,34 \%)$ have been found in leptospirosis; in AVH respectively $100 \%$ and $58,07 \%$. Conjunctival injection frequently has been observed in leptospirosis $(86,17 \%)$ but in AVH has not been occurred $(\mathrm{p}<0,005)$. The occurrences of clinical symptoms and syndromes in both diseases have been compared on Table 1 and Table 2.

Routine laboratory investigations have been demonstrated: leucocytosis $(61,29 \%)$ with neutrophilia and left shift have been found in leptospirosis and ESR is increased in $95,12 \%$ (average $57 \mathrm{~mm}$ per hour; up to 140). Leucocytes have been established in normal range with prevalence of mononuclear cells, normal erythrocytes sedimentation rate (ESR) in $31,30 \%$, moderately increased in $35,08 \%$ and extremely increased ESR only in 9,27\% of cases with AVH. 
Total bilirubin levels have been correlated with severity of both diseases with prevalence of direct bilirubin fraction. Average total bilirubin level in leptospirosis is 152,8 (in severe cases $281 \mathrm{mmol} / \mathrm{L}$ ); in severe AVH $340 \mathrm{mmol} / \mathrm{L}$. In leptospirosis the elevation of aminotransferases is mild to moderate and ASAT level is higher than ALAT (av. respectively $103 \mathrm{U} / \mathrm{L}$ and $94 \mathrm{U} / \mathrm{L}) ;$ increased aminotransferases activity have been correlate with severity of AVH (av. of ALAT ranges from 1730 to $3059 \mathrm{U} / \mathrm{L})(\mathrm{p}<0,005)$. Fibrinogen has been increased frequently in leptospirosis (in $81,01 \%$ of cases; av. $6,7 \mathrm{~g} / \mathrm{L}$ ); in AVH fibrinogen is usually normal and decreased levels have been measured in $17,00 \%$ of cases $(p<0,005)$. Hypoproteinemia and hypoalbuminemia have been presented in severe $\mathrm{AVH}$; in leptospirosis disorders have similar correlation with severity (av. of total protein 65,0 $\mathrm{g} / \mathrm{L}$, albumins - av. $37 \mathrm{~g} / \mathrm{L}$ ). Routine hemogram and liver biochemical parameters in both diseases have been compared on Table 3 and Table 4. Nitrogen parameters are increased often in leptospirosis (normal levels in mild course) up to extremely high levels in cases with acute renal failure (ARF) (av. blood urea nitrogen is $22,9 \mathrm{mmol} / \mathrm{L}$, av. creatinine level is $297 \mathrm{mmol} / \mathrm{L}$ up to $1254 \mathrm{mmol} / \mathrm{L}$ ). Electrolytic and metabolic disorders have been found frequently. In AVH increased nitrogen parameters have been measured only in severe cases with acute liver failure (ALF).

\section{DISCUSSION:}

Different etiology and pathogenesis of both diseases are in the ground of clinical differences. In leptospirosis generalized vasculitis is the major pathomorphological substrate which initiates multi organ disorders such as ARF, hemorrhagic syndrome, cardiovascular and pulmonary alterations (13). ARF is syndrome with greatest significance for severity of leptospirosis. In our research ARF has been presented in $38,30 \%$ of cases with leptospirosis. In AVH we have not observed severe ARF which is controversial with research of Montoliu et al. (1985) (9). Rhabdomyolysis causes muscular pains and contributes acute renal failure (7). Power marker for myocytic damage is creatinkynase which is elevated in leptospirosis $(5,11,12)$. Liver disorders have been observed in both diseases but pathogenic mechanisms are different. In leptospirosis jaundice has complex genesis centrilobular necrosis, microvascular liver disorders and cholestatic compound in absence of severe parenchymal injury which is frequently observed in AVH. ALF is rare complication in leptospirosis (4). These differences correlate with markedly different elevations of aminotransferases and characteristic for each disease changes in fibrinogen and prothrombin index $(8,10,11,12)$. The host immune response involves specific for each disease mechanisms which could explain different changes in routine hemogram in leptospirosis and $\mathrm{AVH}$.

\section{CONCLUSION:}

Same clinical signs with different frequency and severity in both diseases have been presented. Investigations of leucocytes, ESR and liver biochemical parameters have been revealed significant differences. Nitrogen parameters have been increased often in leptospirosis; in AVH only in severe cases with acute liver failure.

Table 1. Clinical syndromes in leptospirosis and acute viral hepatitis

\begin{tabular}{|l|c|c|c|}
\hline Symptoms and syndromes & leptospirosis \% & acute viral hepatitis \% & p \\
\hline acute onset & 100 & 58,01 & $<0,05$ \\
\hline fever & 100 & 58,01 & $<0,05$ \\
\hline adynamia & 90,43 & 82,16 & $>0,05$ \\
\hline nausea and vomiting & 88,30 & 89,03 & $>0,05$ \\
\hline pains in calf muscles & 85,11 & - & $<0,005$ \\
\hline chills & 78,72 & 19,94 & $<0,005$ \\
\hline darkness of urine & 78,72 & 93,60 & $>0,05$ \\
\hline headache & 68,08 & 18,96 & $<0,005$ \\
\hline anorexia & 64,89 & 87,36 & $<0,05$ \\
\hline oliguria & 56,38 & - & $<0,005$ \\
\hline generalized myalgia & 52,13 & 31,55 & $<0,05$ \\
\hline abdominal pains & 46,81 & 17,00 & $<0,05$ \\
\hline lumbar pains & 40,43 & - & $<0,005$ \\
\hline
\end{tabular}




\begin{tabular}{|l|c|c|c|}
\hline hemorrhages & 15,96 & 7,00 & $<0,05$ \\
\hline diarrhea & 13,83 & - & $<0,005$ \\
\hline arthralgia & 9,57 & 9,50 & $>0,05$ \\
\hline photophobia & 8,51 & - & $<0,005$ \\
\hline clay colored stool & 6,38 & 93,60 & $<0,005$ \\
\hline heaviness in abdomen & 3,19 & 84,38 & $<0,005$ \\
\hline
\end{tabular}

Table 2. Clinical syndromes in leptospirosis and acute viral hepatitis

\begin{tabular}{|l|c|c|c|}
\hline Symptoms and syndromes & leptospirosis \% & acute viral hepatitis \% & p \\
\hline hepatomegaly & 91,49 & 100 & $>0,05$ \\
\hline conjunctival injection & 86,17 & - & $<0,005$ \\
\hline splenomegaly & 72,34 & 58,07 & $<0,05$ \\
\hline jaundice & 63,83 & 93,60 & $<0,05$ \\
\hline tachycardia & 53,19 & - & $<0,005$ \\
\hline renal tenderness & 52,13 & - & $<0,005$ \\
\hline hypotension & 47,87 & 76,63 & $<0,05$ \\
\hline abdominal tenderness & 43,62 & 30,37 & $<0,05$ \\
\hline hepatic tenderness & 41,49 & 76,63 & $<0,005$ \\
\hline tachypnea & 14,89 & - & $>0,05$ \\
\hline dyspnea & 11,70 & - & $>0,05$ \\
\hline slowly peristalsis & 8,51 & - & $>0,05$ \\
\hline heart murmurs & 7,45 & - & $>0,05$ \\
\hline labial herpes & 4,45 & - & $>0,05$ \\
\hline rash & 5,32 & 1,62 & $>0,05$ \\
\hline hypertension & 5,32 & - & $>0,05$ \\
\hline
\end{tabular}

Table 3. Routine hemogram in leptospirosis and acute viral hepatitis

\begin{tabular}{|l|c|c|c|}
\hline Laboratory changes & leptospirosis \% & acute viral hepatitis \% & p \\
\hline anemia & 62,69 & 4,63 & $<0,005$ \\
\hline leucocytosis & 61,29 & 11,80 & $<0,005$ \\
\hline granulocytosis & 95,12 & - & $<0,005$ \\
\hline lymphocytosis & - & 14,56 & $<0,005$ \\
\hline ESR - normal & 4,88 & 31,30 & $<0,005$ \\
\hline ESR - moderately increased & 74,39 & 35,08 & $<0,005$ \\
\hline ESR - extremely increased & 20,73 & 9,27 & $<0,005$ \\
\hline thrombocytopenia & 58,62 & 10,30 & $<0,005$ \\
\hline
\end{tabular}


Table 4. Liver biochemical investigations in leptospirosis and acute viral hepatitis

\begin{tabular}{|l|c|c|c|c|c|}
\hline parameters & leptospirosis\% & average & acute viral hepatitis \% & average & p \\
\hline serum bilirubin & 75,00 & 152,8 & 93,60 & 179 & $<0,05$ \\
\hline ASAT & 76,83 & 102,9 & 100 & 1564 & $<0,005$ \\
\hline ALAT & 75,28 & 94,2 & 100 & 2888 & $<0,005$ \\
\hline alkaline phosphatase & 76,47 & 331 & 72,33 & 413 & $>0,05$ \\
\hline GGT & 94,55 & 171 & 83,92 & 309 & $>0,05$ \\
\hline creatinkynase & 77,78 & 1736 & - & - & $<0,005$ \\
\hline total protein & 22,67 & 65,03 & 26,00 & 68 & $>0,05$ \\
\hline albumins & 45,45 & 37,41 & 40,00 & 40 & $>0,05$ \\
\hline fibrinogen & 81,01 & 6,74 & - & 3,01 & $<0,005$ \\
\hline fibrinogen & 1,27 & & 17,00 & & $<0,005$ \\
\hline prothrombin index & 33,33 & 85,6 & 56,00 & 55 & $<0,05$ \\
\hline
\end{tabular}

\section{REFERENCES:}

1. Bounlu K., Insisiengmay S., Vanthanouvong $\mathrm{K}$. et al. Acute jaundice in Vientiane, Lao People's Democratic Republic. Clin Infect Dis. 1998 Oct; 27(4):717-21.

2. Christov Chr., Gancheva G., Georgiev N. et al. Comperative studies in leptospirosis and viral hepatitis in Pleven region. Infectology, 1998; (4):2326. Bulgarian.

3. Cunha B.A. Systemic infections affecting the liver. Some cause jaundice, some do not. Postgrad Med. 1988 Oct; 84(5):148-58, 161-3, 166-8.

4. Deepak N. A., Patel N. D. Differential diagnosis of acute liver failure in India. Ann Hepatol. 2006 JulSep; 5(3):150-6.

5. Johnson W. D. Jr., Silva I. C., Rocha H. Serum creatine phosphokinase in leptospirosis. JAMA. 1975 Sep 1; 233 (9) :981-2.

6. Kothari V. M., Karnad D. R., Bichile LS. Tropical infections in the ICU. J Assoc Physicians India. 2006
Apr; 54:291-8.

7. Mel'nik G. V., Avdeeva M. G., Piskunov O. V. The importance of myoglobin in the pathogenesis of leptospirosis. Ter Arkh. 1997; 69(4):6972. Russian.

8. Mel'nik G. V., Degtiar' L. D., Zhukova L. I. Hepatobiliary alternations in leptospirosis convalescents. Ter Arkh. 2000; 72(2):1821. Russian.

9. Montoliu J., Coca A., MartinezOrozco F., Darnell A. et al. Acute renal failure complicating viral hepatitis in the absence of severe hepatic insufficiency. Am J Nephrol. 1985; 5(5):372-4.

10. Pupkevich-Diamant Ia. S. Certain indicators of enzymograms and their diagnostic value in leptospirosis and viral jaundice. Lab Delo. 1976; (5):289-93. Russian.

11. Pupkevich-Diamant Ia. S., Nisnevich E. B. Activity of dehydrogenases and their isoenzymes in the blood of patients with leptospirosis and viral hepatitis. Lab Delo. 1984; (10):589-93. Russian.

12. Pupkevich-Diamant Ia. S., Nisnevich E. B. Blood enzyme and isoenzyme spectra in leptospiral and viral jaundice. Klin Med (Mosk). 1986 Apr; 64(4):85-91. Russian.

13. Shuvalova E. P., Rakhmanova A. G., Antonova T. V. Characteristics of the pathogenesis of the hemorrhagic syndrome in viral hepatitis and the icteric form of leptospirosis. Klin Med (Mosk). 1984 May; 62(5):93-6. Russian.

14. Ugriumov B. L., Vovk A. D., Alekseeva N. V., et al. Differential diagnosis of Vasiliev-Weil disease. Vrach Delo. 1976 Sep; (9):137-42. Russian.

15. Ugriumov B. L., Vovk A. D., Tat'ianko N. V., Iurkovskaia N. B., Kudriavtseva N. G. Analysis of diagnostic errors in leptospirosis. Vrach Delo. 1980 Nov; (11):112-6. Russian.

\section{Address for correspondence:}

Galya Ivanova Gancheva

Department of Infectious Diseases, University Hospital - Pleven,

8A, Georgy Cochev str., 5800 Pleven, Bulgaria

Tel.: +359/64/886 301; Fax: +359/64/886 439

E-mail: galya_gancheva@abv.bg; 